\title{
NOTES ON THE ORCHID FLORA OF NEW GUINEA I.
}

\author{
Walter KitTredge
}

The following nomenclatural and taxonomic notes are presented as a precursor to a checklist of the orchids of New Guinea currently under preparation. In this first part new generic records as well as new combinations are included. Subsequent parts will include typifications of various sectional names and descriptions of new species. The arrangement of genera follows the system presented by Schlechter in his "Die Orchidaceen von DeutschNeu-Guinea", published in Fedde, Repertorium specierum novarum regni vegetabilis Beihefte 1: 1-1042, 1911-1914.

Peristylus Turneri (Rogers) Kittredge, comb. nov.

Basionym: Habenaria Turneri Rogers, Roy. Soc. S. Austr. 49: $254,1925$.

Anoectochilus papuanus (Schltr.) Kittredge, comb. nov.

Basionym: Eucosia papuana Schltr., Fedde, Rep. Beih. 1:76, 1911.

This is one of several peloric species which Schlechter failed to place correctly. While the peloric lip, lacking a spur, somewhat obscures its generic affinities, this species can definitely be assigned to Anoectochilus. The habit of closely-spaced, ovate, short-petiolate leaves and few-flowered inflorescence of large flowers is entirely that of Anoectochilus, as is the column with its large bifid rostellum placed well behind the two lateral stigmas, and the long Y-shaped pollinarium with a small visicidium. Previous records of Anoectochilus from New Guinea have been identified as species of Macodes.

PNG - Madang Prov., Kani Mts., 1000 m., Schlechter 17361 (AMES!). Morobe Prov., Menyamya Subprov., Piwi'anga, 2000 m., Streiman \& Kairo NGF 35902 (AMES!). 
Erythrodes bicalcaratus (Rogers \& White) Kittredge, comb. nov. Basionym: Physurus bicalcaratus Rogers \& White, Trans. Roy. Soc. S. Austr. 44:110, 1920.

Malaxis cirrhiflora Kittredge, nom. nov.

Basionym: Microstylis stenophylla Schltr., Fedde, Rep. Beih. 1:119, 1911, not Malaxis stenophylla Holttum.

Malaxis cyanobrachis (Schltr.) Kittredge, comb. nov. Basionym: Microstylis cyanobrachis Schltr., Fedde, Rep. 17:371, 1921.

Malaxis dolichostachya (Schltr.) Kittredge, comb. nov.

Basionym: Microstylis dolichostachya Schltr., Bot. Jahrb. 58:59, 1922.

Malaxis euantha (Schltr.) Kittredge, comb. nov.

Basionym: Microstylis euantha Schltr., Fedde, Rep. 16:43, 1919.

Malaxis foliosa Kittredge, nom. nov.

Basionym: Microstylis graciliscapa Schltr., Fedde, Rep. 16:107, 1919, not Malaxis graciliscapa Ames \& Schweinfurth.

Malaxis gibbosa (J. J. Sm.) Kittredge, comb. nov.

Basionym: Microstylis gibbosa J. J. Sm., Bull. Dept. Ag. Ind. Ned. 19:28, 1908.

Malaxis integrilabia (Schltr.) Kittredge, comb. nov.

Basionym: Microstylis integrilabia Schltr., Fedde, Rep. 16:108, 1919.

Malaxis Kempfii (Schltr.) Kittredge, comb. nov.

Basionym: Microstylis Kempfii Schltr., Fedde, Rep. 16:108, 1919.

Malaxis Keysseri (Mansfeld) Kittredge, comb. nov.

Basionym: Microstylis Keysseri Mansfeld, Bot. Jahrb. 62:463, 1929. 
Malaxis Ledermannii (Schltr.) Kittredge, comb. nov.

Basionym: Microstylis Ledermannii Schltr., Bot. Jahrb. 58:60, 1922.

Malaxis pubicallosa (Schltr.) Kittredge, comb. nov.

Basionym: Microstylis pubicallosa Schltr., Fedde, Rep. 17:372, 1921.

Malaxis Stolleana (Schltr.) Kittredge, comb. nov.

Basionym: Microstylis Stolleana Schltr., Bot. Jahrb. 58:62, 1922.

Malaxis vinosa (Schltr.) Kittredge, comb. nov.

Basionym: Microstylis vinosa Schltr., Bot. Jahrb. 58:62, 1922.

Malaxis Werneri (Schltr.) Kittredge, comb. nov.

Basionym: Microstylis Werneri Schltr., Fedde, Rep. 17:373, 1921.

Gynoglottis palaelabellatum (Gilli) Garay \& Kittredge, comb. nov.

Basionym: Coelogyne palaelabellatum Gilli, Ann. Nat. Mus. Wien 84B:22, 1983.

The genus Gynoglottis J. J. Sm. was established for a Sumatran species originally described by Reichenbach as a Coelogyne. The unique habit of Gilli's plant and the unusual long claw of the lip identify it as being congeneric with $G$. cymbidioides (Reich.f.) J. J. Sm. of which I have examined the type. This new record for New Guinea confirms a wider range for the genus first indicated by the doubtful material from the Moluccas.

Dilochia celebica (Schltr.) Schltr., Fedde, Rep. 21:143, 1925.

This new record extends the range of the genus eastwards to include New Guinea. The specimen was originally distributed as a Dendrobium.

IJ-Vogelkop Peninsula, Isjon River valley, from Son to Aifatfekaan, 650 m., Royen \& Sleumer 7842a (AMES!, L). 
Cadetia ledifolia (J. J. Sm.) Kittedge, comb. nov.

Basionym: Dendrobium ledifolium J. J. Sm., Nova Guinea 18:37, 1934.

Diplocaulobium Ridleyanum (Schltr.) Kittredge, comb. nov. Basionym: Dendrobium Ridlevanum Schltr., Schum. \& Laut.

Nachtr. 160, 1905.

Synonyms: Dendrobium reptans Ridley, Journ. Bot. 24:323, 1886, not Swartz 1805, or Fr. \& Sav. 1878.

Dendrobium humifusum Krzl., Pflanzenr. Heft 45:280, 1910.

Diplocaulobium gracilicolle (Schltr.) Kittredge, comb. nov.

Basionym: Dendrobium gracilicolle Schltr., Fedde, Rep. 16:112, 1919.

Trichotosia brachybotrya (Schltr.) Kittredge, comb. nov. Basionym: Eria brachybotrya Schltr., Fedde, Rep. 16:115, 1919.

Trichotosia Gjellerupii Kittredge, nom. nov.

Basionym: Eria integra J. J. Sm., Bull. Jard. Bot. Buit. ser. 2, 3:14, 1912.

Synonym: Trichotosia integra (J. J. Sm.) Hunt, Kew Bull. 26:180, 1971, not Ridley 1917.

Trichotosia hapalostachya (Schltr.) Kittredge, comb. nov. Basionym: Eria hapalostachya Schltr., Fedde, Rep. 16:218, 1919.

Agrostophyllum neoguinense Kittredge, nom. nov.

Basionym: Chitonochilus papuanum Schltr., Schum. \& Laut.

Nachtr. 134, 1905, not Agrostophyllum papuanum Schltr.

This species belongs in Schlechter's section Dolichodesme, and is most closely related to A. paniculatum J. J. Sm. As in A. stenophyllum Schltr., another peloric species of the same section, the lip callus is strongly reduced. The flat stems with distichous leaves, ligulate dark-margined leaf sheaths and wiry bracts at the base of the inflorescence are all characteristic of Agrostophyllum, while the cluster of elongated racemes with small closely- 
sheathing, tubular bracts is identical in structure with the inflorescence of $A$. paniculatum. Schlechter's drawing of the ventral side of the column is misleading, because the lateral view shows the column to be bowed out in front as is the case in most species of Agrostophyllum. The anther contains eight pollinia, not four, as noted by Schlechter, leaving no characters by which to separate Chitonochilus from Agrostophyllum.

PNG, East Sepik Prov., Torricelli Mts. near Apur, 800 m., Schlechter 14420 (AMES!, Isotype).

Bulbophyllum crenilabium Kittredge, nom. nov.

Basionym: Bulbophyllum pictum Schltr., Fedde, Rep. Beih. 1:758, 1913, not Par. \& Rchb. f. 1874

Bulbophyllum densibulbum Kittredge, nom. nov.

Basionym: Bulbophyllum cylindrocarpum Schltr., Fedde, Rep. 16:122, 1919, not Frappier ex Cordem. 1895.

Bulbophyllum gracilicaule Kittredge, nom. nov.

Basionym: Bulbophyllum erectum Rolfe, Trans. Linn. Soc. Bot. 9:186, 1916, not Thou. 1822 .

Bulbophyllum kenejiense Kittredge, nom. nov.

Basionym: Bulbophyllum hydrophilum Schltr., Fedde, Rep. Beih. 1:843, 1913, not J. J. Smith 1905.

Bulbophyllum leptophyllum Kittredge, nom. nov.

Basionym: Bulbophyllum lonchophyllum Schltr., Fedde, Rep. 16:123, 1919, not Schltr. 1913.

Bulbophyllum ligulatum Kittredge, nom. nov.

Basionym: Bulbophyllum eublepharum Schltr., Fedde, Rep. 16:122, 1919, not Bulbophyllum eublepharon Rchb. f. 1862.

Bulbophyllum microlabium Kittredge, nom. nov.

Basionym: Bulbophyllum parvilabium Schltr., Fedde, Rep. 16:126, 1919, not Schltr. 1911. 
Bulbophyllum minutibulbum Kittredge, nom. nov.

Basionym: Bulbophyllum serpens Schltr., Fedde, Rep. Beih. 1:804, 1913, not Lindley 1830.

Bulbophyllum obtusilabium Kittredge, nom. nov.

Basionym: Bulbophyllum rhizomatosum Schltr., Bot. Jahrb. 58:131, 1923, not Ames \& Schweinf. 1920.

Bulbophyllum planifolium Kittredge, nom. nov.

Basionym: Bulbophyllum breviscapum J. J. Sm., Bull. Dept. Ag. Ind. Ned. 39:2, 1911, not (Rolfe) Ridley 1907.

Bulbophyllum rubromaculatum Kittredge, nom. nov.

Basionym: Bulbophyllum nigrescens Schltr., Fedde, Rep. Beih. 1:839, 1913, not Rolfe 1910.

Bulbophyllum sepikense Kittredge, nom. nov.

Basionym: Bulbophyllum cuspidipetalum Schltr., Bot. Jahrb. 58:132, 1923, not J. J. Sm. 1908.

Bulbophyllum singuliflorum Kittredge, nom. nov.

Basionym: Bulbophyllum nemorosum Schltr., Fedde, Rep. Beih. 1:884, 1913, not Cogn. 1902.

Bulbophyllum tristelidium Kittredge, nom. nov.

Basionym: Bulbophyllum tridentatum Rolfe, Kew Bull. p. 128, 1907, not Krzl. 1901.

Monomeria digitata (J. J. Sm.) Kittredge, comb. nov.

Basionym: Bulbophyllum digitatum J. J. Sm., Bull, Jard, Bot. Buit, ser. 2, 2:18, 1911.

The transfer of this species to Monomeria makes J. J. Smith's monotypic section Gongorodes a synonym of the genus, which is recorded here from New Guinea for the first time.

Octarrhena bilabrata (Royen) Kittredge, comb. nov.

Basionym: Kerigomnia bilabrata Royen, Contr. Herb. Austr. 12:2, 1976. 
An examination of mature buds from the Ames isotype reveals that there are eight unequal pollinia in the anther, not two as reported by Royen, confirming his original placement of this species in the Thelasiinae. There are five species in Octarrhena which share with $O$. bilabrata the eight unequal pollinia and the unusual protruding column, but which differ in habit, having long multiflowered inflorescences.

PNG, Eastern Highlands Prov., Goroka Subprov., near Kerigomna camp, 3000 m., Hoogland \& Pullen 5525 (AMES!, L! Isotypes).

The following key is offered to differentiate the species related to Octarrhena bilabrata:

1. Inflorescences short, 4-8 mm long, 1-3-flowered 0 . bilabrata

1a. Inflorescences longer, 2-9 cm in length, many-flowered ...2

2. Lip adnate to column pouch in lower half .. $\mathbf{0}$. calceiformis

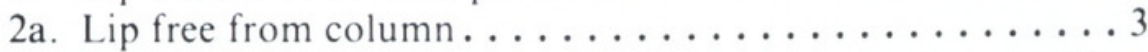

3. Lip linear-ligulate .............. . cucullifera

3a. Lip broader, ovate, oblong or triangular . . . . . . 4

4. Inflorescence 1, subterminal, peduncle long, ovary smooth to slightly rugulose ............... obovata

4a. Inflorescence(s) 1-many, axillary from any part of stem, peduncle short, ovary warty $\ldots \ldots \ldots \ldots \ldots \ldots$

5. Leaves $8-15 \mathrm{~mm}$ long, petals obtuse to truncate... O. gracilis

5a. Leaves $17-25 \mathrm{~mm}$ long, petals acute ..... O. cupulilabra

Octarrhena teretifolia (Gilli) Kittredge, comb. nov.

Basionym: Dendrochilum teretifolium Gilli, Ann. Nat. Mus. Wien 84B:31, 1983.

This species is closely allied to $O$. arfakensis $\mathrm{J}$. J. Sm. and $O$. cylindrica J. J. Sm. from which it differs in having orbicular petals and an invagination at the apex of the lip calli.

PNG, Western Highlands Prov., Laiagam, 2850 m., Gilli 461 (W! Holotype).

Thelasis abbreviata (Schltr.) Kittredge, comb. nov. Basionym: Oxyanthera abbreviata Schltr., Fedde, Rep. Beih. 1:906, 1913. 
Thelasis papuana (Schltr.) Kittredge, comb. nov.

Basionym: Oxyanthera papuana Schltr., Schum. \& Laut. Nachtr. p. 126, 1905.

In describing the peloric form of Thelasis carinata B1. in Nova Guinea 14:492, 1929, J. J. Smith stated that Oxyanthera papuana should be regarded as a synonym of $T$. carinata. An examination of Schlechter's collections reveals two prominent differences between these species which merit their separation. The first, mentioned by Schlechter, is that the flowers of T. papuana are nearly twice as large as those of $T$. carinata. The second is that $T$. papuana has a pair of stelidia at the apex of the column which are absent in $T$. carinata.

PNG: Bismarck Mts., 350 m., Schlechter 18658 (AMES!).

Phreatia clivicola Kittredge, nom. nov.

Basionym: Phreatia collina Schltr., Fedde, Rep. Beih. 1:9191, 1913, not J. J. Sm. 1911. 


\section{$2 \mathrm{BHL}$ Biodiversity Heritage Library}

Kittredge, Walter. 1985. "Notes on the Orchid Flora of New Guinea I." Botanical Museum leaflets, Harvard University 30(2), 95-102. https://doi.org/10.5962/p.168674.

View This Item Online: https://www.biodiversitylibrary.org/item/31877

DOI: https://doi.org/10.5962/p.168674

Permalink: https://www.biodiversitylibrary.org/partpdf/168674

\section{Holding Institution}

Missouri Botanical Garden, Peter H. Raven Library

\section{Sponsored by}

Missouri Botanical Garden

\section{Copyright \& Reuse}

Copyright Status: Public domain. The BHL considers that this work is no longer under copyright protection.

This document was created from content at the Biodiversity Heritage Library, the world's largest open access digital library for biodiversity literature and archives. Visit BHL at https://www.biodiversitylibrary.org. 